\title{
FORMÁT VÝUKY PŘEVRÁCENÉ TŘíDY V ON-LINE PROSTŘEDÍ V HODINÁCH HOSPODÁŘSKÉ ANGLIČTINY NA VYSOKÉ ŠKOLE
}

\author{
Tereza Havránková \\ Západočeská univerzita v Plzni, Fakulta pedagogická, Katedra anglického jazyka, \\ Chodské náměstí 1, 30614 Plzeň, Česká republika \\ e-mail: truzicko@kan.zcu.cz
}

\begin{abstract}
Abstrakt
Koncept výuky převrácená tř́da se stal v posledních letech využívaným př́istupem především $\mathrm{v}$ hodinách matematiky a př́rodních věd. Závěry různých studií ale ukazují, že převrácenou tř́du lze úspěšně implementovat i do online výuky cizích jazyků. Článek popisuje probíhající výzkum, jehož záměrem je prozkoumat dopad režimu převrácené tř́́dy na studijní výsledky studentů hospodářské angličtiny na vysoké škole v online výuce. Úvod článku je věnován teoretickým poznatkům o problematice převrácené trrídy $\mathrm{v}$ online prostředí. Druhá část je věnována metodologii samotného výzkumu a přehledu dílčích zjištění výzkumu, realizovaného v letním semestru akademického roku 2020/2021.
\end{abstract}

\section{Key words}

Flipped classroom; Flipped learning; Research design; Digital technology; SOFLA.

\section{Úvod}

Předkládaný článek se zabývá inovativním pedagogickým př́stupem (modelem převrácená tř́da), pro nějž je zásadním tématem implementace digitálních nástrojů do školské výuky. Moderní informační technologie se v posledních letech již staly pevnou součástí každodenní pedagogické praxe [1] a nestojí již pouze na okraji zájmu vyučujících. Ti již naprosto běžně používají k vyhledávání informací a studijních podkladů internet, pouštějí studentům videa z Youtube a prripravují si rozmanité prezentace. Stále více z nich zapojuje do výuky též mnohé složitější aplikace či nástroje (např. tablety), jež dokážou lépe udržet pozornost studentů, kteří internet a chytré mobilní telefony či rozmanité sociální sítě využívají ve své každodenní praxi naprosto běžně.

Výzkumy a odborná literatura zabývající se aplikací digitálních nástrojů do výuky však stále častěji dokládají, že tyto technologie mají především skutečný potenciál zásadním způsobem zvýšit kvalitu a efektivitu výuky každého oboru [2]. Jsou schopné nejen zvýšit zájem studentů o probírané téma, ale i zajistit jejich aktivní zapojení se do výuky, zlepšit jejich studijní výsledky a motivovat je $\mathrm{k}$ dalšímu zájmu o obor i mimo školní prostředí.

Nicméně je však nezbytné, aby byl každý vyučující schopen tyto nástroje využívat efektivně a způsobem, který mu pomůže naplnit především jeho pedagogické cíle. Tím nejdůležitějším totiž nejsou samotné využívané nástroje, ale především metoda a způsob jejich zpracování a zapojení [1]. Ani moderní informační technologie proto nemohou být nadřazeny samotné pedagogice, ale mohou být chytrými „,zbraněmi““ v rukách zkušených a koncepčně schopných „manažerů výuky“.

Autorka předkládaného výzkumu při své odborné práci nezůstala u zájmu o digitální technologie, ale zabývá se především vhodnými metodami a postupy, jak je co nejfunkčněji využívat v pedagogické praxi. Její dlouholetá zkušenost pedagožky jí totiž ukázala, že učitelé 
jsou dnes $\mathrm{v}$ rámci různých kurzů běžně seznamováni $\mathrm{s}$ různorodými novými digitálními nástroji. Není jim však vytyčen přesný postup, jak všechny tyto jednotlivosti ve výuce využívat $\mathrm{k}$ tomu nejdůležitějšímu - koncepčnímu směřování výuky $\mathrm{k}$ pochopení a zapamatování si probíraného učiva. Rozhodla se proto zabývat se uceleně konkrétním modelem výuky, jenž může být na digitálních nástrojích snadno postaven. Pro tento model ale tyto nástroje nejsou nejstěžejnější částí výuky. Jeho hlavním účelem je především dosažení stanovených pedagogických cílů [1].

Vybraným formátem je model převrácené třídy. Ten je založen na maximálním využití času určeného pro prezenční/synchronní výuku. Dosahuje toho přesunutím prezentace nového obsahu (lektorování) do domácí prŕípravy / asynchronního prostředí. Na základě pedagogem vytvořených výukových podkladů (např. ve formě videí) se studenti s obsahem učiva seznámí sami doma před samotnou výukou. Ta na domácí přípravu navazuje a probíraný obsah dále rozvíjí prostřednictvím dalších metod aktivní výuky (např. prací ve skupinách, role plays, diskuse) [3]. Předkládaná práce se důsledně zaměřila na využívání digitálních nástrojů právě ve fázi domácí prŕpravy ( $\mathrm{v}$ asynchronním prostředí), kdy byla pro studenty $\mathrm{k}$ vysvětlení jednotlivé látky zpracovávána instruktážní videa, obsahující tzv. „embbeded questions“ (vložené kontrolní otázky). V rámci prezenční výuky (popř. v době pandemie Covid-19 online výuky) pak bylo možné probranou látku dále rozvíjet tradičními postupy či také využít další digitální nástroje (Padlet, Jamboard, Sli.do apod.). Postavení př́evrácené výuky na využití videí je odborníky považováno za postup výrazně odpovídající moderním trendům. Podle těchto trendů je způsob, jakým dnešní mládež vstřebává nové podněty, výrazně postaven právě na vizuálních a filmových prvcích [2].

Formát převrácené třídy je aktuálně hojně využíván především v př́irodovědných oborech [4], avšak jeho efektivita se postupně potvrzuje naprríč předměty. Autorka se proto rozhodla tento model aplikovat ve výuce jazyků (konkrétně hospodářské angličtiny) a přinést tak poznatky z oblasti, která dosud není častým cílem výzkumných studií [5].

\section{$1 \quad$ Teoretická východiska}

\section{$1.1 \quad$ Synchronous Online Flipped Learning (SOFLA)}

Převrácená třída nebyla původně navržena do on-line výuky [6], nýbrž do výuky prezenční. Tato výuková metoda se však během posledních let stala velice populární i v on-line výuce, obzvlášt' během pandemie Covid-19. Dle principů převrácené třŕdy v online výuce se studenti v asynchronní části výuky seznámí s novým obsahem pomocí videí nebo interaktivních pracovních listů. Synchronní část výuky je zaměřena na aktivní učení a prohlubování znalostí dané problematiky [4]. V roce 2011 Marshallová a Rodriguezová [6] představily pojem tzv. převrácené třídy určený do on-line prostředí a v roce 2020 Marshallová a Kostka [6], model SOFLA upravily a definovaly osmi kroky (1. domácí příprava, 2. úvod/přihlášení, 3. aktivity pro celou třídu, 4. práce ve skupinách, 5. sdílení a zpětná vazba, 6. upoutávka, 7. zadání domácího úkolu, 8. závěrečná reflexe), které jsou navrženy tak, aby výuka byla efektivní a zároveň vycházela $\mathrm{z}$ principů převrácené třídy.

První krok je domácí př́prava, která je přesunuta do asynchronního prostředí. Během domácí př́pravy studenti pracují samostatně, svým vlastním tempem a seznamují se s novým obsahem. Nový obsah by měl být zpracovaný interaktivním způsobem v aplikaci, která umožní učitelům vkládat otázky, na které studenti odpovídají a zároveň získávají zpětnou vazbu. Studenti mají v domácí př́pravě i možnost klást přes LMS dotazy spolužákům a učitelům. Krok 2, přihlášení, je aktivita, kdy učitel položí studentům otevřené otázky týkající se domácí př́ípravy, aby zjistil, jak studenti novému obsahu porozuměli. Studenti odpovídají na otázky v Google dokumentu nebo Padletu, aby byly odpovědi všem dostupné. 
Krok 3, aktivity pro celou tř́du, je zaměřen na problémy nebo nejasnosti, na které studenti narazili během domácí prípravy. Všichni studenti v této fázi pracují společně, např. v aplikaci Jamboard nebo Whiteboard. Následuje krok 4, kdy studenti pracují ve skupinách a společně vypracovávají nějaký zadaný úkol. Po práci ve skupinkách studenti sdílejí výstupy své práce a navzájem si dávají zpětnou vazbu. $V$ dalších dvou krocích učitel nejdříve studenty motivuje na domácí přípravu a následně jim ukáže, jaké je zadání domácí př́ípravy na další hodinu. Poslední částí je závěrečná reflexe, kterou studenti vypracovávají samostatně do sdíleného dokumentu nebo Padletu. Studenti mají za úkol napsat reflexi z hodiny [6].

Model SOFLA (Fig. 1) je strukturované schéma pro výuku ve formátu převrácené tř́idy v online prostředí, ale umožňuje učitelům být kreativní a zaměřit obsah jednotlivých kroků na dosažení výukových cílů [6].
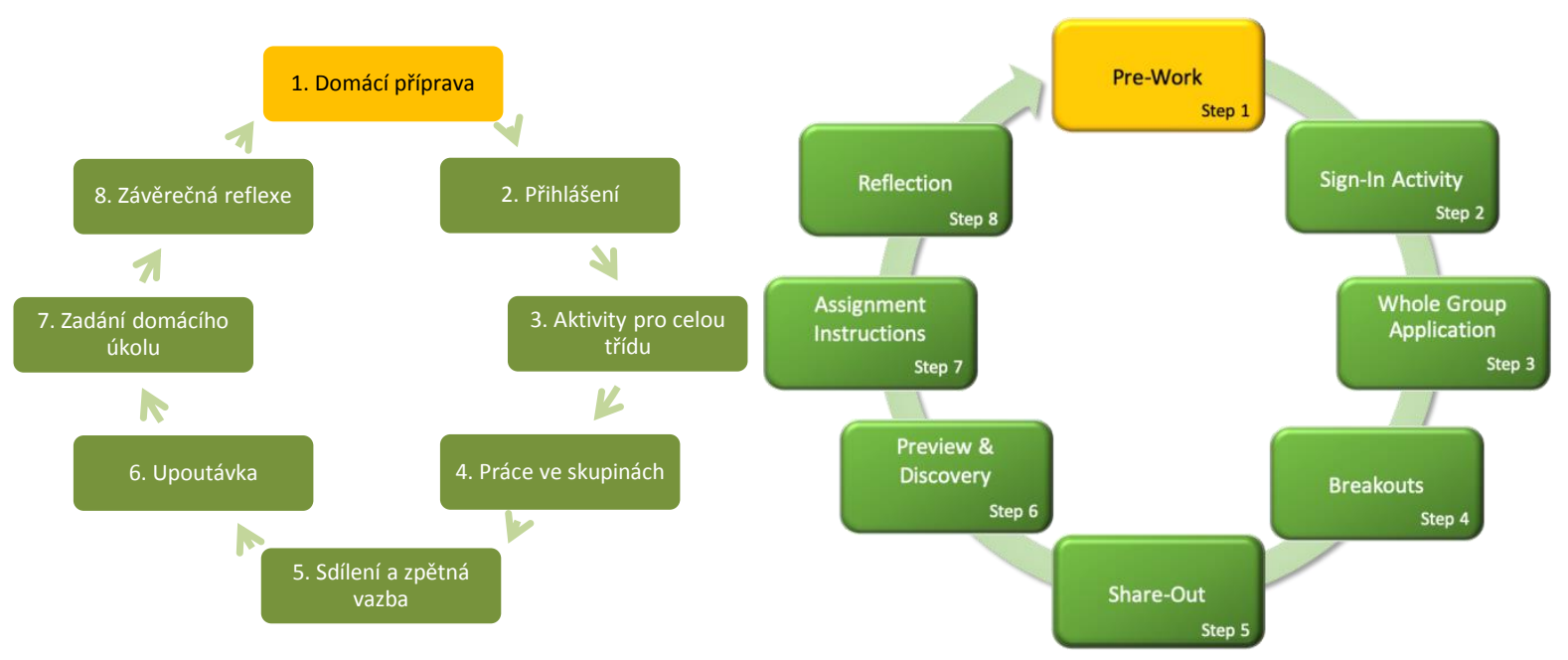

Zdroj: [6]

Fig. 1: Model SOFLA

\section{Cíle a výzkumné otázky}

Snahou autorky je vyplnit mezery v empirickém poznání konceptu převrácené tř́ídy ve výuce anglického jazyka, a to s využitím digitálních nástrojů. Širším cílem realizovaného výzkumu je proto předložit přehled dosavadního bádání a vhodných aplikací, ale především v praktické části práce zjistit a popsat, jaký má model převrácená tř́da dopad na výuku (tj. prověřit efektivitu daného výukového modelu při výuce anglického jazyka). Toto bylo zjišstováno na uceleném výzkumném vzorku běžných studenti̊ standardního semináře hospodářské angličtiny na Fakultě ekonomické Západočeské univerzity v Plzni.

Autorka se rozhodla odborně se formátem převrácené třídy zabývat především díky svým zkušenostem z dlouholeté pedagogické praxe a zájmu o aktivní a účelné využívání digitálních nástrojů při výuce cizích jazyků. Tento postup vnímá jako efektivní metodu, která má potenciál zvýšit intenzitu zapojení studentů do výuky (interakci mezi vyučujícím a studenty i mezi nimi navzájem) a zlepšit jejich znalosti i jazykové dovednosti. Dále oceňuje vhodnost modelu pro zapojení digitálních nástrojů do výuky a jejich aktivní využívání jak učitelem, tak žákem. Tento formát je proto nejen funkční, ale i moderní a vyhovuje požadavkům 21. století. Na základě své pedagogické praxe autorka jako hlavní nevýhodu daného formátu vnímá vyšší časovou náročnost, která je kladena na studenty. Toto je však dle zkušeností autorky vyváženo především lepšími výsledky studentů zapojených do výuky $\mathrm{v}$ režimu převrácené tř́̉dy, což je kvantifikovatelně ověřitelné díky běžným testům v rámci vysokoškolských hodin.

Metodologie praktického výzkumu byla od počátku formulování výzkumného záměru postavena na realizaci $\mathrm{v}$ prezenčních hodinách a aktivní osobní interakci vyučujícího se 
studenty (i studentů navzájem). Tento záměr zásadním způsobem narušila zcela neočekávatelná situace spjatá s pandemií Covid-19. Především následná vládní opatření, kdy byla jakákoliv výuka na vysokých školách realizována po tři semestry téměř výhradně v online prostředí, realizaci výzkumu v připravené podobě znemožnila. Po ustálení situace se proto realizátorka výzkumu rozhodla flexibilně přepracovat své výzkumné postupy a nástroje pro zkoumání efektivity využívání modelu převrácené tř́́dy výuky anglického jazyka v online prostředí.

Maxwell připomíná, že realizace výzkumu obecně má pozitivní vliv na hlubší pochopení jakékoliv problematiky hned v několika rovinách: intelektuální, praktické a personální [7]. I autorka předkládané práce vnímá zásadní přínos daného výzkumného záměru právě ve vrstevnatosti jeho prŕnosu. Na intelektuální úrovni si totiž klade za cíl přinést nejnovější poznatky o konceptu převrácené tř́idy $\mathrm{v}$ hodinách anglického jazyka na základě prozkoumání zahraničních a českých zdrojů. Výzkum přispěje k analýze výsledků těchto prací. Autorka se zaměří na popsání výhod a nevýhod tohoto modelu ve výuce anglického jazyka v prezenční i on-line výuce na vysokých školách. Zásadní přínos práce je však možné vnímat především $\mathrm{v}$ jeho praktické rovině. Výsledky výzkumu totiž přinesou bohaté poznatky o fungování převrácené třídy $\mathrm{v}$ hodinách jazyků $\mathrm{v}$ on-line prostředí a mohou tak reálným pedagogům pomoci tento výukový model poznat a pochopit. Učitelé budou moci na základě předložených poznatků a závěrů výzkumu převrácenou třídu implementovat ve své běžné praxi a využívat jej při své online výuce, stejně jako ozkoušet některé z navrhovaných vhodných aplikací. Na osobní/personální úrovni přinese realizovaný výzkum zásadní efekt i pro samotnou autorku zpracovávané práce. Ta díky němu získá poznatky a schopnosti, které dále rozvinou její pedagogické a osobní dovednosti, a pomohou jí vylepšit a upravit studijní plány předmětu Hospodářské angličtiny na Fakultě ekonomické ZČU. Dále autorce daný výzkum ukáže efektivní postupy, jak tento model výuky integrovat do svých hodin anglického jazyka.

Výzkum ve výše popsané podobě konkrétně probíhal v letním semestru akademického roku 2020/2021 v šesti paralelních třídách, kde tři kontrolní skupiny (K1, K2, K3) byly vyučovány tradičním zpo̊sobem a tři experimentální skupiny $(\mathrm{E} 1, \mathrm{E} 2, \mathrm{E} 3) \mathrm{v}$ režimu převrácené třídy. Tímto způsobem disertační práce $\mathrm{v}$ těchto skupinách studentů obchodní angličtiny ověří efektivitu výuky založené na formátu převrácená třída, a to konkrétně ve výuce s využitím moderních technologií a v online prostředí.

\section{Hlavním cílem práce tak je:}

Prozkoumat limity a možnosti modelu převrácené tř́ídy s využitím digitálních technologií při výuce AJ na vysoké škole v českém prostředí.

Tento hlavní cíl je dále rozdělen do tří dílčích cílů, které přispějí k naplnění cíle hlavního.

\section{Dílčí cíle práce jsou:}

1. Analyzovat dopad modelu převrácená trrída na studijní výsledky studentů ve výuce anglického jazyka.

2. Popsat vliv daného modelu s využitím moderních nástrojů na průběh prezenční části výuky.

3. Interpretovat postoje studentů daného modelu s využitím moderních nástrojů $\mathrm{z}$ pohledu studentů.

Dílčí cíle předkládané práce lze také vnímat ve více rovinách.

Východiska: Vypracovat přehled realizovaných výzkumů v ČR a zahraničí. 


\section{Analytická část:}

- Analyzovat dopad modelu převrácené trrídy na studijní výsledky studentů ve výuce anglického jazyka.

- Popsat hlavní výhody a nevýhody daného formátu při výuce anglického jazyka. Interpretovat postoje studenti̊ na daný model v souvislosti s aktivním zapojením v online hodinách. Aplikační a návrhová část:

- Na základě získaných poznatků zpracovat přehled aplikací, které jsou vhodné pro výuku v modelu převrácené třídy.

- Vytvořit metodiku pro implementaci modelu převrácená třída do výuky anglického jazyka.

Konkrétně si autorka si v rámci praktické části výzkumu klade následující výzkumné otázky:

1. Jaký vliv má model převrácené třídy na studijní výsledky studentů semináře Hospodářská angličtina na VŠ ve srovnání s tradiční výukou?

2. Jaké jsou hlavní negativní či pozitivní dopady režimu převrácené tř́ídy na průběh prezenční/synchronní části výuky?

3. Jaké hlavní aspekty daného formátu (kladné či záporné) vnímají studenti z experimentální skupiny?

Na základě studia předchozích dostupných výzkumů a literatury k tématu převrácené tř́ídy předkládá autorka následující hypotézu pro první dílčí cíl:

Studenti z experimentální skupiny maji statisticky vyšši skóre ze závěrečného testu než studenti vyučování tradičním zpưsobem.

Logiku výzkumného záměru přehledně shrnuje Tabulka 1.

Tab. 1: Přehled cílù výzkumu

\begin{tabular}{|c|c|c|c|}
\hline & Dílčí cíle & Výzkumné otázky & Hypotézy \\
\hline 1 & $\begin{array}{l}\text { Analyzovat dopad } \\
\text { převrácené tř́idy na } \\
\text { studijní výsledky } \\
\text { studentů ve výuce } \\
\text { anglického jazyka }\end{array}$ & $\begin{array}{l}\text { Jaký vliv má model převrácené } \\
\text { třídy na studijní výsledky } \\
\text { studentů semináre Hospodářská } \\
\text { angličtina na VŠ ve srovnání } \\
\text { s tradiční výukou? }\end{array}$ & $\begin{array}{l}\text { Studenti z experimentální } \\
\text { skupiny mají statisticky vyšší } \\
\text { skóre ze závěrečného testu } \\
\text { než studenti vyučovaní } \\
\text { tradičním způsobem. }\end{array}$ \\
\hline 2 & $\begin{array}{l}\text { Popsat vliv daného } \\
\text { modelu s využitím } \\
\text { moderních nástrojů na } \\
\text { průběh prezenční / } \\
\text { synchronní části výuky. }\end{array}$ & $\begin{array}{l}\text { Jaké jsou hlavní negativní či } \\
\text { pozitivní dopady modelu } \\
\text { převrácené třídy na průběh } \\
\text { prezenční / synchronní části } \\
\text { výuky? }\end{array}$ & \\
\hline 3 & $\begin{array}{l}\text { Interpretovat postoje } \\
\text { studentů na př́evrácenou } \\
\text { třídu s využitím } \\
\text { digitálních nástrojů. }\end{array}$ & $\begin{array}{l}\text { Jaké hlavní aspekty daného } \\
\text { formátu (kladné či záporné) } \\
\text { vnímají studenti } \\
\text { z experimentální skupiny? }\end{array}$ & \\
\hline
\end{tabular}


Metodologie výzkumu byla inspirována výzkumem autorů Given Leeové a Amandy Wallaceové, který byl v roce 2016 realizován na Univerzitě v Jižní Koreji [8]. Cílem výzkumu bylo zjistit, jaký dopad má převrácená třída na studijní výsledky vysokoškolských studentů obecného anglického jazyka. Výzkum probíhal dva semestry a zapojilo se do něj celkem 79 studentů. Výzkum byl založen na pedagogickém experimentu, kde byly porovnávány čtyři skupiny studentů. Dvě experimentální skupiny byly vyučovány v principu převrácené třídy a dvě kontrolní skupiny byly vyučovány tradičním způsobem. Výsledky výzkumů ukazují, že $\mathrm{v}$ závěrečném testu $\mathrm{z}$ anglického jazyka dosáhli studenti z experimentální skupiny lepších výsledků než studenti z kontrolní skupiny. Průměrná dosažená hodnota ze závěrečného testu studentů z experimentální skupiny byla 19,44 bodů z celkových 25 bodů. Průměrné výsledky kontrolní skupiny byly 17,55 bodů z celkových 25 . Výsledky závěrečných testů mají statisticky významný výsledek $(t=2,172, p=0,033)$ [8].

Výzkumný tým práce navázal na výše zmíněný výzkum a navrhl design studie, jež měla být aplikována do hodin Hospodářské angličtiny 2 na vysoké škole v prezenční formě během letního semestru akademického roku 2020/21. Tento záměr ale zásadním způsobem narušila zcela neočekávaná situace spjatá s pandemií Covid-19 a především s následnými vládními nařízeními, kvůli nimž byly již tři semestry vyučovány téměř výlučně v online prostředí. Po ustálení situace se realizační tým výzkumu rozhodl flexibilně přepracovat jeho design a přizpůsobit ho možnostem konceptu převrácené třídy v on-line prostředí.

Výzkumný tým realizoval výzkum v on-line výuce předmětu Hospodářská angličtina 2, kdy byly tři skupiny studentů vyučovány ve stylu převrácené tř́́dy a tři skupiny tradičním způsobem. Studenti z experimentální skupiny byli seznámeni s novým obsahem před výukou pomocí výukových videí. Asynchronní výuka se zaměřovala na procvičení nového učiva. Naproti tomu kontrolní skupina byla seznámena s novým obsahem během synchronního vyučování a zbytek hodiny byl věnovaný procvičení dané problematiky.

\subsection{Výzkumný vzorek}

Účastníci výzkumu jsou studenti prvního ročníku Fakulty ekonomické ZČU. Studenti Fakulty ekonomické mají ve svém studijním plánu dva semestry hospodářské angličtiny. Během měsíce zárí jsou budoucí studenti prvních ročníků zkoušeni z anglického jazyka. Každý student je povinen složit zkoušku Cambridge Placement Test. Tato zkouška probíhá $\mathrm{v}$ prostorách Ústavu jazykové př́ípravy a zkoušku studenti skládají on-line formou. Dle výsledků testu jsou budoucí studenti prvního ročníku FEK rozděleni na dvě skupiny - na skupinu s jazykovou úrovní anglického jazyka B1/B2 dle Evropského referenčního rámce pro jazyky, a na skupinu s úrovní B1. Následně studenti s vyšší jazykovou úrovní v zimním semestru absolvují seminář Hospodářská angličtina 3 a v letním semestru seminář Hospodářská angličtina 4. Studenti, kteří v rozřazovacím testu dosáhli jazykové úrovně B1 a nižší, si v zimním semestru zapíší seminář Hospodářská angličtina 1 a v letním semestru seminář Hospodářská angličtina 2. V zimním semestru je předmět Hospodářská angličtina zakončen zápočtovým testem, $\mathrm{v}$ letním semestru pak zápočtovým testem a zkouškou. Zápočtový test se skládá ze 4 částí: poslech, gramatika, čtení a psaní. Účastníci experimentu byli studenti semináŕe Hospodářské angličtiny 2 které vyučovala samotná autorka této práce. Studenti tohoto semináře by měli mít jazykovou úroveň B1, ale jsou zde i studenti, kteří mají jazykovou úroveň anglického jazyka daleko nižší. Ve skupinách tak vzniká velká jazyková nerovnost mezi jednotlivými studenty.

Vzhledem k přechodu na online výuku během letního semestru 2020/2021 byl zaznamenán znatelný úbytek studentů, kteří ve studiu $\mathrm{v}$ letním semestru na FEK pokračovali. 
Z plánovaných 60 studentů, kteří se měli původně do experimentu zapojit, se nakonec zapojilo pouze studentů 50. Tito studenti byli náhodně rozděleni do čtyř skupin, dvě skupiny experimentální (E1, E2) a dvě skupiny kontrolní $(\mathrm{K} 1, \mathrm{~K} 2)$. V rámci experimentu se následně do výzkumu zapojily i dvě skupiny cca. 30 studentů předmětu Hospodářské angličtina 2, které vyučuje lektorka z Ústavu jazykové př́pravy. V rámci experimentu vedla druhá vyučující výuku v jedné experimentální a druhé kontrolní skupině. Celkem se do experimentu zapojilo 80 studentů.

Všichni studenti z experimentální skupiny byli na první hodině semináře informováni o zapojení do experimentální skupiny a požádáni o informovaný souhlas. Všichni studenti se zapojením do experimentu souhlasili a žádný student nepožádal o přesun do jiné skupiny.

\subsection{Výzkumné metody}

Na základě teoretických východisek a rešerší již realizovaných výzkumů v oblasti výukového modelu převrácené tř́́dy se výzkumný tým rozhodl pro smíšený typ výzkumu. Data byla získána na základě kvantitativních i kvalitativních metodologických př́istupů a tyto odlišné metodologické př́stupy se tak mohou doplňovat.

Data získaná během výzkumu budou pocházet $\mathrm{z}$ následujících zdrojů: pretestu, dvou dotazníků, posttestu, strukturovaných rozhovorů a poznámek vyučujícího, viz design výzkumu

Výzkumný tým navrhl následující metody výzkumu pro splnění dílčích cílů:

Dílčí cíl č. 1: Jaký vliv má model převrácená třída na studijní výsledky studentio semináre Hospodářrská angličtina na VŠ ve srovnání s tradiční výukou?

$\mathrm{K}$ dosažení tohoto cíle se výzkumný tým rozhodl pro sběr dat na základě kvantitativního př́stupu. Získaná data budou pocházet z pretestu a posttestu a následně budou analyzována pomocí inferenční statistiky. Stanovená hypotéza je:

Studenti z experimentální skupiny mají statisticky vyšší skóre ze závěrečného testu než studenti z kontrolní skupiny (studenti vyučovaní tradičním způsobem).

$\mathrm{Na}$ začátku a na konci experimentu budou všichni studenti podrobeni pretestu a posttestu $\mathrm{z}$ anglického jazyka. Tyto testy byly vytvořeny pedagogy Ústavu jazykové př́pravy pro předmět Hospodářská angličtina 2 a otestovány na studentech $\mathrm{v}$ předcházejících letech. Výsledky testů z experimentální skupiny a kontrolní skupiny budou analyzovány a porovnány využitím dvou statistických metod Studentovým parametrickým $t$-testem a MannWhitneyovým neparametrickým. Před analýzou dat bude vybrán vhodný software, např. Gretl, pro zpracování statistických dat získaných z pretestu a posttestu.

Dílčí cíl č. 2: Jaké jsou hlavní negativní či pozitivni efekty modelu prevrácená tř́da na průběh výuky?

\section{Dílčí cíl č. 3: Jaké hlavni aspekty daného formátu (kladné či záporné) vnímaji studenti?}

Tyto cíle budou dosaženy kvantitativním a kvalitativním přístupem výzkumu. Kvantitativní data budou pocházet ze dvou dotazníků, které budou analyzovány deskriptivní metodou. Během pedagogického experimentu byli studenti ze všech skupin požádáni o vyplnění dvou dotazníků. Tyto dotazníky obsahovaly cca 20 otázek kvantitativního a kvalitativního charakteru a byly určeny jak pro experimentální, tak pro kontrolní skupiny.

Oba dotazníky byly dokončeny v průběhu měsíce ledna 2021. Dotazníky byly následně rozeslány pěti expertům, kteří se $\mathrm{k}$ jejich obsahu vyjádřili. Na základě vyjádření expertů a pilotáži dotazníků byly dotazníky upraveny a doplněny. 
Přehled způsobu sběru dat v jednotlivých dílčích cílech shrnuje Tabulka 2.

Tab. 2: Přehled způsobu sběru dat v jednotlivých dílčích cílech

\begin{tabular}{|l|l|l|l|}
\hline \multicolumn{1}{|c|}{ Dílčí cíle } & \multicolumn{1}{c|}{ Výzkumné otázky } & \multicolumn{1}{c|}{$\begin{array}{c}\text { Metody sběru } \\
\text { a interpretace dat }\end{array}$} \\
\hline 1 & $\begin{array}{l}\text { Analyzovat dopad modelu } \\
\text { převrácené třídy na } \\
\text { studijní výsledky studentů } \\
\text { ve výuce anglického } \\
\text { jazyka }\end{array}$ & $\begin{array}{l}\text { Jaký vliv má model převrácená } \\
\text { třída na studijní výsledky } \\
\text { studentů seminář Hospodářská } \\
\text { angličtina na VŠ ve srovnání } \\
\text { s tradiční výukou? }\end{array}$ & $\begin{array}{l}\text { pretest, posttest } \\
\text { Data budou analyzována } \\
\text { Studentovým } t \text {-testem a } \\
\text { Mann Whitneyovým } U \\
\text { testem }\end{array}$ \\
\hline 2 & $\begin{array}{l}\text { Popsat vliv daného } \\
\text { modelu s využitím } \\
\text { moderních nástrojů na } \\
\text { průběh prezenční části } \\
\text { výuky. }\end{array}$ & $\begin{array}{l}\text { Jaké jsou hlavní negativní či } \\
\text { pozitivní dopady modelu } \\
\text { převrácené tř́dy na průběh } \\
\text { prezenční / synchronní části } \\
\text { výuky? }\end{array}$ & $\begin{array}{l}\text { vstupní a závěrečný } \\
\text { dotazník polostrukturované } \\
\text { rozhovory poznámky } \\
\text { vyučujíć́ho } \\
\text { Data budou analyzována } \\
\text { kvantitativní a kvalitativní } \\
\text { metodou. }\end{array}$ \\
\hline 3 & $\begin{array}{l}\text { Interpretovat postoje } \\
\text { studentů na převrácenou } \\
\text { tř́du s využitím } \\
\text { digitálních nástrojů } \\
\text { z pohledu studentů. }\end{array}$ & $\begin{array}{l}\text { Jaké hlavní aspekty daného } \\
\text { formátu (kladné či záporné) } \\
\text { vnímají studenti? }\end{array}$ & $\begin{array}{l}\text { závěrečný dotazník } \\
\text { polostrukturované } \\
\text { rozhovory } \\
\text { Data budou analyzována } \\
\text { kvantitativní a kvalitativní } \\
\text { metodou }\end{array}$ \\
\hline
\end{tabular}

Zdroj: Vlastní

\section{$4 \quad$ Dosavadní výsledky výzkumu}

Následující část článku je přehled dosavadních výsledků z výzkumu, který byl realizován během letního semestru akademického roku 2020/21.

\subsection{Zpracování výukových videí do asynchronní části výuky}

Autorka výzkumu vytvořila vlastní výuková videa a zároveň použila již dostupné záznamy dohledatelné na YouTube. Následně videa uložila do aplikace EdPuzzle. EdPuzzle (edpuzzle.com) je aplikace, která umožňuje zpracování výukových videí. Podle Leeové a Wallaceové [8] několik studentů z jejich výzkumu přiznalo, že výuková videa by byla mnohem zajímavější, kdyby obsahovala interaktivní prvky. Aplikace EdPuzzle tyto prvky na tvorbu interaktivních videí nabízí. Umožňuje učiteli vkládat do libovolného videa otázky (otevřené otázky, multiple choice), na které musí studenti během videa odpovídat. Aplikace neumožňuje studentům pokračovat ve zhlédnutí videa, aniž by odpověděli na př́slušné otázky. Dále tato aplikace nabízí okamžitou zpětnou vazbu ohledně splnění a správnosti odpovědí žáků. Učitel tak získá informace o tom, kdy žáci video zhlédli, zda video viděli celé, jaké části videa si pustili opakovaně. Tato data mohou být následně využita $\mathrm{k}$ ohodnocení porozumění studenta dané látce a $\mathrm{k}$ zaměření samotné výuky na ty části, které nejsou studentům zcela jasné [5]. Další výhodou této aplikace je, že učitel může vybrat video ze široké nabídky zdrojů TedEx, YouTube, Khan Academy, National Geographic nebo použít již upravená videa, která byla nasdílena jinými učiteli.

Autorka projektu vytvořila ve webové aplikaci Edpuzzle bezplatný účet, který se může využívat zdarma pro tvorbu až 5 videí. Jelikož bylo v rámci tohoto výzkumu použito více 
videí, autorka projektu zaplatila premium verzi této aplikace. Po vytvoření účtu vznikly třídy Hospodářská angličtina 2. Studenti semináře následně získali vstupní kód, pomocí kterého se přihlásili do aplikace pod svým jménem. Tento kód byl identický pro celý letní semestr a studenti po zadání tohoto kódu do aplikace EdPuzzle získali přístup k výukovým videím. Studenti bylimailem upozorněni na každé nové video, které bylo nahráno do složky Hospodářská angličtina 2. Autorka projektu získala přehled o tom, kolik studentů video vidělo, kolikrát si video přehráli a jak studenti odpovídali na kontrolní otázky.

Celkem bylo zpracováno 24 výukových videí. Videa byla zaměřena na gramatiku, slovní zásobu obchodní angličtiny a strategie mluvení a čtení. Použitá videa byla natočena a namluvena samotnou autorkou projektu, rodilou mluvčí z USA, zároveň k danému účelu posloužila videa z YouTube. Každé video bude dále upraveno v aplikaci EdPuzzle a doplněno otázkami k získání okamžité zpětné vazby. Odpovědi studentů byly zaznamenávány a uchovávány v samotné aplikaci EdPuzzle.

\subsection{Pretest a Posttest}

První a poslední týden letního semestru akademického roku 2020/21 studenti z kontrolních i experimentálních skupin vyplnili on-line standardizovaná, ověřené zápočtové testy pro předmět Hospodářská angličtina 2, vytvořené vyučujícími tohoto předmětu na Ústavu jazykové přípravy ZČU. Testy se skládaly z několika částí - poslechu, části zaměřenou na gramatiku a slovní zásobu, čtení a psaní. Pro zajištění jejich korektního vyplnění byly testy zadány při online výuce a všichni studenti měli povinnost mít zapnutý mikrofon a kameru. Testy byly zpracovány v Google Forms a parametry testů nastaveny tak, aby studenti nemohli mezi jednotlivými částmi překlikávat. Mohli pouze vždy jít na následující stranu testu, ale nemohli se $\mathrm{v}$ něm vrátit na předchozí stranu. Pořadí otázek bylo pro každý test náhodně změněno. Na vyplnění testu měli studenti 60 minut a všichni tento časový limit splnili.

\subsubsection{Vyhodnocení testů (pretest, posttest)}

Pro každou ze tří experimentálních (E1, E2 a E3) a kontrolních (K1, K3, K3) skupin bylo provedeno vyhodnocení počtu bodů, které studenti těchto skupin dosáhli v pretestu (před započetím výuky) a v posttestu (po skončení výuky). Základní hodnoty souboru jsou uvedeny v Tabulce 3 .

Tab. 3: Základni statistické charakteristiky souboru skupin studenti̊

\begin{tabular}{|l|c|c|c|c|c|}
\hline & \multicolumn{2}{|c|}{ Pretest } & \multicolumn{2}{c|}{ Postetst } & \\
\cline { 1 - 2 } & Průměr & Sm. odch. & Průměr & Sm. odch. & $n$ \\
\hline ES1 & 33,1 & 5,8 & 39,6 & 3,9 & 15 \\
\hline KS1 & 30,8 & 4,9 & 36,7 & 8,8 & 12 \\
\hline ES2 & 32,8 & 4,2 & 39,5 & 4,0 & 16 \\
\hline KS2 & 31,8 & 6,9 & 38,7 & 5,3 & 19 \\
\hline ES3 & 33,2 & 6,6 & 44,3 & 4,7 & 19 \\
\hline KS3 & 31,1 & 5,3 & 42,3 & 5,5 & 16 \\
\hline
\end{tabular}

Zdroj: Vlastní

Posun v průměrném bodovém zisku u každé skupiny je na obrázku Fig. 2. 


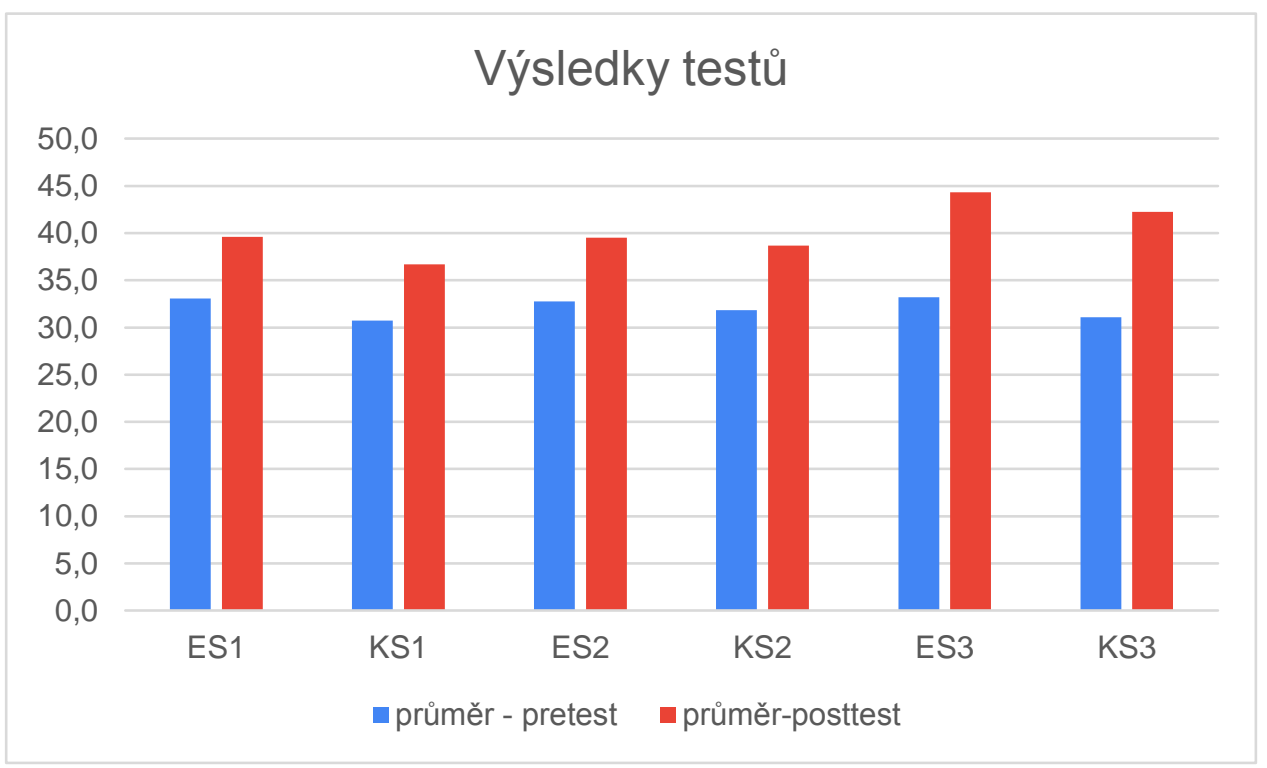

Zdroj: Vlastní

Fig. 2: Výsledky pretestu a postestu

Pozitivní je, že u všech skupin došlo ke zvýšení bodového zisku mezi pretestem a posttestem.

Pokud sloučíme všechny výsledky z kontrolních skupin do jednoho souboru a stejně tak z experimentálních skupin, dostaneme charakteristiky souboru, které ukazuje Tabulka 4:

Tab. 4: Souhrnné statistiky souboru student z experimentálních a kontrolních skupin

Zdroj: Vlastni

\begin{tabular}{|c|c|c|c|c|c|}
\hline & \multicolumn{2}{|c|}{ Pretest } & \multicolumn{2}{c|}{ Postetst } & \multirow{2}{*}{ Posttest - Pretest } \\
\hline & Průměr & Sm. odch. & Průměr & Sm. odch. & Pon \\
\hline Es & 33,0 & 5,5 & 41,4 & 4,2 & 8,3 \\
\hline Ks & 31,3 & 5,7 & 39,4 & 6,6 & 8,1 \\
\hline
\end{tabular}

Pomocí tzv. krabicového grafu (Fig. 3) byly vyneseny průměry (kř́žek), medián (čára), kvartily (okraj krabice), maxima, minima bez odlehlých hodnot a odlehlé hodnoty. 


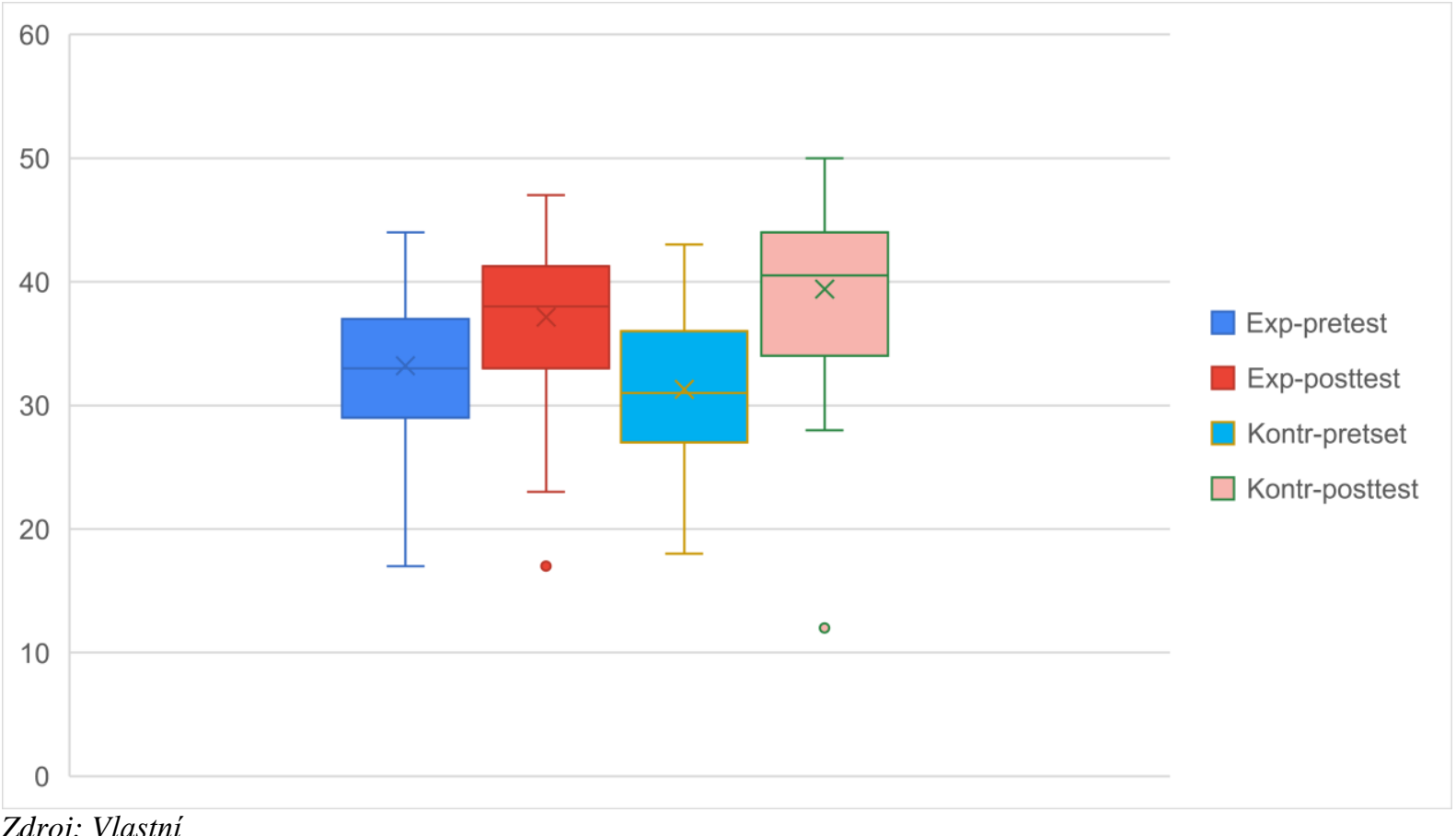

Zdroj: Vlastní

Fig. 3: Výsledky pretestu a postestu

Po prověření normality rozdělení (Shapirovu-Wilkovu testu normality) byl proveden Studentův $t$-test na rozdíl středních hodnot. Již z obrázku, ale také provedeným testem se ukázalo, že rozdíl středních hodnot souboru bodového zisku u studentů kontrolní skupiny a experimentální skupiny není statisticky významný (na běžně používané hladině významnosti 0,05).

Obě skupiny (experimentální i kontrolní) si zlepšily své bodové hodnocení o cca 8 bodů.

Mírným pozitivem je, že experimentální skupina má o něco menší rozptyl hodnot souboru (mezi studenty experimentální skupiny jsou o něco menší rozdíly ve znalostech).

Hypotéza o významně lepších výsledcích experimentální skupiny se nepotvrdila.

\subsection{Dotazníkové šetření}

$\mathrm{V}$ rámci výzkumu bylo provedeno dotazníkové šetření na začátku a na konci semestru akademického roku 2020/21. Dotazníky byli určeny pro studenty jak z experimentální, tak i z kontrolní skupiny. Pro zajištění 100\% návratnosti dotazníkủ byly dotazníky zadány studentům během on-line výuky. Otázky prvního dotazníku měly pomoci autorovi práce získat přehled o tom, kdo byli studenti předmětu Hospodářská angličtina 2. Otázky jsou zaměřené na pohlaví, věk studentů a dále na studovaný obor a ročník studia anglického jazyka.

Druhý dotazník byl rozdělen na dvě části. První část dotazníku byla zaměřena obecně na jednotlivé fáze výuky předmětu Hospodářská angličtina 2, jako je např́iklad organizace výuky, obsah, úkoly, prezentace nového obsahu, procvičování, a zpětnou vazbu. Druhá část dotazníku byla určena pouze pro studenty z experimentální skupiny a obsahovala otázky cílené na postoje $\mathrm{k}$ převrácené tř́ídě.

Oba dotazníky budou analyzovány kvantitativně i kvalitativně. Kvantitativní typy otázek budou analyzovány deskriptivní metodou. Ukončení interpretace dotazníků bude do konce měsíce ř́ijna 2021. 


\subsection{Poznámky vyučující}

Autorka výzkumu si jako další nástroj pro sběr dat zvolila poznámky/deník z on-line výuky v experimentální a kontrolní skupině. Poznámky nebyly zaznamenávány dle žádného předem pevně stanoveného formátu, ale na základě dění ve tř́iě, jako byly postřehy ze spoluprací a komunikací studentů při jednotlivých aktivitách, klima ve třídě nebo zapojení se studentů do různých typů aktivit. Zápisky budou interpretovány kvalitativní metodou a přinesou vhled do problematiky z pohledu zúčastněného pozorovatele výuky - samotného pedagoga.

Data z poznámkového aparátu budou analyzována do konce roku 2021.

\subsection{Polostrukturované rozhovory}

V průběhu měsíce června a července 2021 proběhly polostrukturované rozhovory se studenty z experimentálních skupin. Polostrukturované rozhovory jsou vhodné v př́padě, kdy nemáme na rozhovor mnoho času, rozhovor nemůžeme opakovat, nebo chceme předejít snižování kvality rozhovoru ze strany tazatele, Hendl [9]. Celkem se rozhovorů zúčastnilo 16 studentů, kteří souhlasili $\mathrm{s}$ účastí na polostrukturovaných rozhovorech a zároveň spadali do skupiny studentů vykazujících průměrné studijní výsledky v předmětu Hospodářská angličtina 2. Otázky rozhovoru byly zaměřené na dovysvětlení jednotlivých částí závěrečného dotazníku týkající se interakce se spolužáky a učitelem, časové náročnosti a postojů $\mathrm{k}$ výukovému modelu převrácené tř́dy $\mathrm{v}$ on-line prostředí. Rozhovory se uskutečnily přes aplikaci ZOOM. Následně budou přepsány pomocí softwaru Otter.ai a kódovány pomocí softwaru Atlas.ti. Původním záměrem bylo provést rozhovor $\mathrm{s}$ deseti respondenty, ale $\mathrm{z}$ důvodu nasycení teoretických dat byl počet respondentů navýšen na celkových patnáct.

Polostrukturované rozhovory budou analyzovány, přepsány a analyzovány pomocí zakotvené teorie v průběhu srpna až prosince 2021.

\section{$5 \quad$ Poučení z výzkumu a návrhy pro zlepšení}

Snaha autorky předložených tezí je nezůstat pouze u popisu daného modelu výuky a jeho efektivity s použitím moderních technologií ve výuce anglického jazyka, nýbrž nabídnout i poučení a navrhnout možná řešení pro co nejfunkčnější implementaci modelu do běžné výuky. Součástí výzkumné práce tak bude i metodika, která rozšíří využitelnost dané metody v učitelské praxi jiných učitelů anglického jazyka.

Zároveň bude zpracována rešerše nejvhodnějších digitálních nástrojů pro výuku ve formátu převrácený třídy. Tato rešerše bude obsahovat přehled digitálních nástrojů, které se autorce během výzkumu osvědčily. V průběhu experimentu již nyní bylo prokázáno, že pro efektivitu výuky v převrácené třídě není zásadní kvantita využívaných aplikací, ale především schopnost pedagogů efektivně a účelně využívat i menší počet zvolených aplikací.

\section{Závěr}

Převrácená třída je inovativním modelem výuky, který se v posledních letech stal předmětem výzkumných prací napříč různými obory, a to včetně výuky anglického jazyka. Závěry výzkumných šetření poukazují na výhody tohoto modelu, mezi něž patří zlepšení studijních výsledků nebo častější interakce studentů ve výuce. Zároveň realizovaná šetření v dané problematice akcentují nevýhody tohoto modelu, např́klad časovou náročnost na př́ípravu ze strany učitele i studentů.

Autorka práce chce navázat na již realizované výzkumy a prozkoumat limity a možnosti převrácené tř́́dy s využitím digitálních technologií. Tím může doplnit poznatky o tomto modelu v rámci výuky i anglického jazyka v českém kontextu. 
V rámci práce byla na základě prostudované literatury stanovena teoretická východiska, která dala základ pro stanovení cílů práce a poskytla rámec pro tvorbu samotné metodologie výzkumu. Součástí př́prav na samotný výzkum byla realizace dotazníkového šetření. To mělo ukázat, jak správně zpracovat výuková videa tak, aby jejich obsah a zpracování co nejvíce rezonovaly $\mathrm{s}$ potřebami studentů. Výsledky tohoto šetření následně pomohly autorce zpracovat 24 výukových videí prezentující nový obsah učiva v aplikaci EdPuzzle.

Samotný výzkum byl zahájen v letním semestru akademického roku 2020/21. Vzhledem k okolnostem spojených s pandemií Covid-19 a následným uzavřením vysokých škol byl výzkum přizpůsoben výuce v on-line prostředí.

V průběhu výzkumu probíhal také sběr dat kvantitativního a kvalitativního charakteru. Sběr dat byl ukončen na konci měsíce srpna a data budou následně analyzována a interpretována. Výsledky pretestu a posttestu pro experimentální a kontrolní skupinu byly podrobeny statistické analýze. Analýza výsledků pretestu a posttestu ukázala, že hypotéza o významně lepších výsledcích experimentální skupiny se nepotvrdila.

Autorka chce ve své práci postoupit o krok dál a nezůstat jen u přehledu literatury, popisu a analýzy výukového formátu převrácené tř́ídy. $\mathrm{Na}$ základě výzkumných šetření hodlá vytvořit pro učitele anglického jazyka metodiku pro co nejfunkčnější zařazení daného formátu a digitálních nástrojů do běžné pedagogické praxe.

\section{Literatura}

[1] ZOUNEK, J.; JUHAŇÁK, L.; STAUDKOVÁ, H.; POLÁČEK, J.: E-learning. Učení (se) s digitálními technologiemi. Wolters Kluwer ČR, a.s., Praha, 2016. 280. s. ISBN 978-80-7552-217-7.

[2] WANG, N.: New Digital Technology in Education, Conceptualizing Professional Learning for Educators. Springer International Publishing, Switzerland, 2015. ISBN 978-3-319-05821-4.

[3] SITNÁ, D.: Metody aktivního vyučování. Portál, Praha, 2013. ISBN 978-80-262-04046.

[4] BERGMANN, J.: Flip your classroom: reach every student in every class every day. International Society for Technology in Education, 2012. ISBN 978-1-56484-315-9.

[5] MEHRING, J.: Present Research on the Flipped Classroom and Potential Tools for the EFL Classroom. Computers in the Schools. 2016, Vol. 33, Issue 1. DOI: $\underline{10.1080 / 07380569.2016 .1139912}$

[6] MARSHALL, H. W.; KOSTKA, I.: Fostering Teaching Presence through the Synchronous Online Flipped Learning Approach. Teaching English as a Second or Foreign Language. 2020, Vol. 24, Issue 2. Available from WWW: https://www.teslej.org/wordpress/issues/volume24/ej94/ej94int/

[7] MAXWELL, J. A.: Qualitative research design. An Interactive Approach. Sage, Thousand Oaks, London, New Delhi, 2005. ISBN 0761926089.

[8] LEE, G., WALLACE, A.: Flipped Learning in the English as a Foreign Language Classroom: Outcomes and Perceptions. TESOL Quarterly. 2018, Vol. 52, Issue 1, pp. $62-84$. DOI: $\underline{10.1002 / \text { tesq. } 372}$

[9] HENDL, J.: Kvalitativní výzkum. Portál, Praha, 2005. ISBN 978-80-7367-485-4.

Mgr. Tereza Havránková 


\section{THE SyNCHRONOUS ONLINE FLIPPED LEARNING APPROACH (SOFLA) IN BUSINESS ENGLISH COURSES}

The flipped classroom model has been an appealing approach to teaching, primarily in math and science classes. However, several research studies have proven that the flipped classroom method can be successfully implemented in online language classes. This article presents a research study that aims to analyze the impact of the flipped learning approach on Czech university students in English classes. The first part of the study is dedicated to the goals and methodology of the research. The second section discusses the partial outcomes of the research.

\section{FORMAT EINER UMGEKEHRTEN KLASSE IM ONLINE-UNTERRICHT BEI DER LEHRE VON WIRTSCHAFTSENGLISCH AN DER HOCHSCHULE}

Das Unterrichtskonzept für eine umgekehrte Klasse wurde in den letzten Jahren zu einem oft genutzten Ansatz vor allem beim Unterricht der Mathematik und der Maturwissenschaften. Die Schlüsse der verschiedenen Studien zeigen jedoch, dass sich eine umgekehrte Klasse auch erfolgreich im Online-Unterricht für Fremdsprachen implementieren lässt. Dieser Artikel beschreibt eine noch nicht abgeschlossene Untersuchung, deren Ziel in der Erforschung der Auswirkung des Regimes der umgekehrten Klasse auf die Studienergebnisse der Studenten des Wirtschaftsenglisch an der Hochschule beim Online-Unterricht besteht. Die Einleitung des Beitrags erwähnt die theoretischen Erkenntnisse hinsichtlich der Problematik der umgekehrten Klasse im Online-Milieu. Der zweite Teil widmet sich der Methodologie der eigentlichen Untersuchung sowie dem Überblick über die Teilfeststellungen der Untersuchung, welche im Sommersemester des akademischen Jahres 2020/21 durchgeführt wurde.

\section{ZAJĘCIA METODĄ ODWRÓCONEJ KLASY W ŚRODOWISKU ON-LINE NA LEKCJACH EKONOMICZNEGO JĘZYKA ANGIELSKIEGO NA UCZELNI WYŻSZEJ}

Nauka w trybie odwróconej klasy stała się w ostatnich latach koncepcją stosowaną przede wszystkich na zajęciach z matematyki i nauk przyrodniczych. Wnioski wynikające z różnych badań wskazują jednak, że odwróconą klasę można $\mathrm{z}$ sukcesem wprowadzić także w nauczaniu on-line języków obcych. W artykule opisano przeprowadzane badania, których celem jest zbadanie wpływu trybu odwróconej klasy na osiągnięcia studentów uczęszczających na zajęcia ekonomicznego języka angielskiego na uczelni wyższej prowadzone $\mathrm{w}$ formie on-line. We wstępie artykułu przedstawiono wiedzę teoretyczną dotyczącą zagadnienia odwróconej klasy w środowisku on-line. W drugiej części opisano metodologię badań oraz zaprezentowano wybrane wnioski wynikające $\mathrm{z}$ badań, przeprowadzonych $\mathrm{w}$ semestrze letnim roku akademickiego 2020/2021. 